\title{
LOGAM BERAT PADA HIU TIKUS (Alopias pelagicus) DAN HIU KEJEN (Loxodon macrorhinus) DARI PELABUHAN PERIKANAN SAMUDERA LAMPULO, BANDA ACEH
}

\author{
Ilham Zulfahmi ${ }^{1,2 \star}$, Dewi Nola Nasution ${ }^{1}$, Khairun Nisa ${ }^{3}$, Yusrizal Akmal ${ }^{4}$ \\ ${ }^{1}$ Pusat Kajian dan Konservasi Akuatik, Universitas Islam Negeri Ar-Raniry, Kota Pelajar dan Mahasiswa, Darussalam, \\ Banda Aceh 23111, Aceh, Indonesia. \\ ${ }^{2}$ Program Studi Biologi, Fakultas Sains dan Teknologi, Universitas Islam Negeri Ar-Raniry, \\ Kota Pelajar dan Mahasiswa, Darussalam, Banda Aceh 23111, Aceh, Indonesia. \\ ${ }^{3}$ Program Studi Tarbiyah Biologi, Fakultas Tarbiyah dan Keguruan, Universitas Islam Negeri Ar-Raniry, \\ Kota Pelajar dan Mahasiswa, Darussalam, Banda Aceh 23111, Aceh, Indonesia. \\ ${ }^{4}$ Program Studi Akuakultur, Fakultas Pertanian, Universitas Almuslim, \\ Jalan Almuslim, Matang Glumpang Dua, Peusangan, Bireuen 24261, Aceh, Indonesia.
}

^Korespondensi: ilham.zulfahmi@ar-raniry.ac.id

Diterima: 30 Januari 2020/Disetujui: 30 April 2020

Cara sitasi: Zulfahmi I, Nasution DN, Nisa K, Akmal Y. 2020. Kandungan logam berat pada hiu tikus (Alopias pelagicus) dan hiu kejen (Loxodon macrorhinus) dari Pelabuhan Perikanan Samudera Lampulo, Banda Aceh. Jurnal Pengolahan Hasil Perikanan Indonesia. 23(1): 47-57.

\begin{abstract}
Abstrak
Hiu merupakan salah satu jenis ikan yang berpotensi tercemar logam berat. Hal ini karena hiu memiliki sebaran yang luas dan tergolong ke dalam konsumen tingkat tinggi pada jejaring makanan akuatik. Informasi terkait kandungan logam berat pada ikan hiu hasil tangkapan di Indonesia masih sedikit. Penelitian ini bertujuan untuk menentukan kandungan logam berat $(\mathrm{Pb}, \mathrm{Hg}, \mathrm{Cu}$ dan $\mathrm{Cd}$ ) dan batas aman konsumsi daging hiu tikus (Alopias pelagicus) dan hiu kejen (Loxodon macrorhinus) yang didaratkan di Pelabuhan Perikanan Samudera Lampulo, Banda Aceh. Sebanyak sepuluh contoh dari masing-masing daging hiu tikus dan hiu kejen dianalisis kandungan logam beratnya menggunakan metode spektrofotometri serapan atom. Penentuan batas aman konsumsi dari daging hiu dilakukan menggunakan metode maximum tolerable intake (MTI). Hasil penelitian mengungkap dari 20 sampel daging hiu tikus dan hiu kejen yang diperiksa, keberadaan $\mathrm{Pb}, \mathrm{Cu}$ dan $\mathrm{Cd}$ tidak terdeteksi. Sebaliknya, 60\% dari total hiu yang diperiksa (baik hiu kejen maupun hiu tikus) terdeteksi mengandung $\mathrm{Hg}$. Kandungan rata-rata Hg pada hiu tikus berkisar antara 0,007 - 0,768 mg/kg sedangkan pada hiu kejen berkisar antara $0,030-0,708 \mathrm{mg} / \mathrm{kg}$. Batas toleransi maksimum daging hiu tikus yang dapat dikosumsi oleh orang dewasa dan anak-anak dalam waktu satu minggu menurut SNI adalah masing masing sebesar $1,690 \mathrm{~kg} /$ minggu dan 0,507 kg/minggu. Sementara itu, batas toleransi maksimum daging hiu kejen yang dapat dikosumsi oleh orang dewasa dan anak-anak dalam waktu satu minggu menurut SNI 7387 adalah masing masing sebesar 2,112 kg/minggu dan 0,633 kg/minggu.
\end{abstract}

Kata kunci: batas aman konsumsi, hiu tikus, hiu kejen, merkuri, pencemaran

\section{Heavy Metal Concentration in Pelagic Thresher (Alopias pelagicus) and Sliteye Shark (Loxodon macrorhinus) from Ocean Fishing Port of Lampulo, Banda Aceh}

\begin{abstract}
Shark has been known to be potentially contaminated by heavy metals. This occurs due to their wide distribution and play an important role as the apex predator in the aquatic food chain. However, information underlying the heavy metal content in sharks from Indonesia waters is still very rare. Therefore, this study was aimed to determine the concentration of heavy metals $(\mathrm{Pb}, \mathrm{Hg}, \mathrm{Cu}$, and $\mathrm{Cd})$ and estimate the maximum tolerable intake of pelagic thresher (Alopias pelagicus) and sliteye shark (Loxodon macrorhinus) for consumption. Heavy metal content of twenty fillets samples from both were analyzed with the atomic absorption spectrophotometry method. The potential human health risks due to consumption of the sharks was assessed using maximum tolerable intake (MTI). Results showed that, from 20 samples of both examined, the presence of $\mathrm{Pb}, \mathrm{Cu}$, and $\mathrm{Cd}$ was not detected. Otherwise, $60 \%$ of the total sharks examined both were contained $\mathrm{Hg}$. Concentration of $\mathrm{Hg}$ in pelagic thresher ranged from 0.007 to $0.768 \mathrm{mg} /$ $\mathrm{kg}$ while in sliteye shark ranged form $0.030-0.708 \mathrm{mg} / \mathrm{kg}$. The maximum tolerable intake of pelagic thresher meat that can be consumed by adults and children within a week according to SNI were $1.690 \mathrm{~kg} / \mathrm{week}$ and $0.507 \mathrm{~kg} / \mathrm{week}$, respectively. The maximum tolerable intake of sliteye shark meat that can be consumed by adults and children within a week according to SNI 7387 are $2.112 \mathrm{~kg} /$ week and $0.633 \mathrm{~kg} /$ week, respectively.
\end{abstract}

Keywords: maximum tolerable intake, mercury, pelagic thresher, pollution, sliteye shark 


\section{PENDAHULUAN}

Timbel $(\mathrm{Pb})$, merkuri $(\mathrm{Hg})$, tembaga $(\mathrm{Cu})$ dan kadmium (Cd) merupakan kelompok logam berat yang masih dimanfaatkan sebagai bahan baku pembuatan amunisi, baterai, cat, keramik, kosmetik, racun serangga, minyak pelumas hingga perlengkapan medis (Agustina 2014). Kontaminasi logam berat ini berpotensi mencemari perairan melalui berbagai aktivitas antropogenik yaitu pemukiman, aktivitas pelabuhan, dan limbah industri (Siregar dan Edward 2010; Amin et al. 2012). Cemaran logam berat di perairan Aceh telah dilaporkan terjadi di beberapa lokasi yaitu Krueng Raya, Aceh Besar (Astuti et al. 2016), kawasan pelabuhan nelayan Gampong Deah, Kota Banda Aceh (Rizkiana et al. 2017), Pelabuhan Jetty Meulaboh, Aceh Barat (Warni et al. 2017) serta perairan pesisir Kota Lhokseumawe dan Aceh Utara (Komarawidjaja et al. 2017).

Kontaminasi logam berat dalam tubuh organisme akuatik terutama ikan dapat terjadi melalui penetrasi kulit, pernapasan, serta konsumsi makanan yang sudah terkontaminasi (Hidayah et al. 2014). Logam berat bersifat akumulatif di dalam tubuh organisme akuatik dan cenderung sulit untuk diekskresikan. Efek negatif yang ditimbulkan oleh logam berat dilaporkan mampu menghambat laju pertumbuhan ikan (Rahayu et al. 2017), merusak jaringan organ hati dan ginjal ikan (Maftuch et al. 2015), serta menurunkan kinerja reproduksi ikan (Zulfahmi et al. 2014; Zulfahmi et al. 2015).

Hiu merupakan salah satu jenis ikan yang berpotensi tercemar logam berat. Hal ini disebabkan karena hiu memiliki sebaran yang luas dan tergolong ke dalam konsumen tingkat tinggi pada jejaring makanan akuatik yang berumur panjang (Das et al. 2003; Mohammed \& Mohammed 2017). Penelitian terkait kandungan logam berat pada hiu telah dilaporkan oleh beberapa peneliti sebelumnya. Lopes et al. (2013) mengungkapkan bahwa konsentrasi logam berat khususnya merkuri dan timbal pada Prionace glauca di perairan Pasifik tenggara mencapai $0,048 \pm 0,03 \mu \mathrm{g} / \mathrm{g}$ dan 1,996 $\pm 0,67 \mu \mathrm{g} / \mathrm{g}$, melebihibatas keamanan pangan yang diizinkan untuk kandungan timbal. Mohammed \& Mohammed (2017) menyatakan bahwa dua jenis hiu komersial (Sphyrna lewini dan Carcharinus porosus) di Trinidad dan Tobago memiliki kandungan merkuri, arsenik, kadmium dalam konsentrasi tinggi sehingga berpotensi mengganggu kesehatan manusia apabila dikonsumsi secara berlebihan.

Pelabuhan Perikanan Samudera (PPS) Lampulo merupakan pelabuhan pendaratan ikan (termasuk hiu) terbesar dalam kawasan Kota Banda Aceh. Lesmana et al. (2018) mengungkapkan selama bulan Februari hingga April 2018, terdapat 747 individu hiu yang didaratkan di pelabuhan ini. Hiu tersebut terdiri dari 16 famili, 20 genus dan 32 jenis. Hiu tikus (Alopias pelagicus) dan hiu kejen (Loxodon macrorhinus) merupakan dua jenis hiu yang dominan didaratkan di PPS Lampulo.

Sejauh ini penelitian hiu di indonesia masih terbatas pada tahap identifikasi (Lesmana et al. 2018), aspek biologi dan fluktuasi hasil tangkapan (Dharmadi et al. 2012), serta status konservasi (Alaydrus et al. 2014). Informasi terkait kandungan logam berat pada hiu hasil tangkapan di Indonesia masih belum diungkap. Sulistiono et al. (2018) menyatakan bahwa penelitian terkait kandungan logam berat pada organisme akuatik diperlukan sebagai acuan untuk menghindari dampak buruk logam berat apabila masuk kedalam tubuh manusia. Akumulasi logam berat pada tubuh manusia dapat menyebabkan penyakit pada sistem pernafasan, kerusakan ginjal, kemandulan, gangguan sistem saraf pusat dan fungsi otak, kerusakan kromosom, kerusakan sperma, kanker,gangguan psikologis, diaredan berbagai penyakit kulit (Agustina 2014; Sudarmaji et al. 2006; Indirawati 2017). Penelitian ini bertujuan mengukur kandungan logam berat $(\mathrm{Pb}, \mathrm{Hg}, \mathrm{Cu}$ dan $\mathrm{Cd})$ dan batas aman konsumsi daging hiu tikus (Alopias pelagicus) dan hiu kejen (Loxodon macrorhinus) yang didaratkan di PPS Lampulo.

\section{BAHAN DAN METODE Bahan dan Alat}

Bahan-bahan yang digunakan dalam penelitian ini meliputi daging hiu tikus dan hiu kejen, asam nitrat $\left(\mathrm{HNO}_{3}\right)$, asam perklorat 
$\left(\mathrm{HClO}_{4}\right)$, asam sulfat $\left(\mathrm{H}_{2} \mathrm{SO}_{4}\right)$, potasium persulfat $\left(\mathrm{K}_{2} \mathrm{~S}_{2} \mathrm{O}_{8}\right)$, kalium permanganat $\left(\mathrm{KMNO}_{4}\right)$ (Merck), standar logam $\mathrm{Pb}, \mathrm{Cu}, \mathrm{Cd}$ dan $\mathrm{Hg}$, akuades dan akuabides. Sementara itu, alat-alat yang digunakan yaitu cool box, alat bedah, freezer, meteran, timbangan analitik (Mettler Toledo AL-204), peralatan gelas (Pyrex), hot plate (Cimarec), dan atomic absorption spectrophotometer (AAS) (Shimadzu tipe AA-7000, Jepang)

\section{Metode Penelitian Pengumpulan sampel}

Pengambilan sampel daging hiu dilakukan di PPS Lampulo Kuta Alam, Kota Banda Aceh (5.56 62'11" LU dan 95'33'55.21"BT), sedangkan pengukuran kandungan logam berat pada daging dilakukan di Laboratorium Balai Riset dan Standardisasi Industri, Banda Aceh. Analisis data dilakukan di Laboratorium Ekologi, Program Studi Biologi, Fakultas Sains dan Teknologi, Universitas Islam Negeri ArRaniry, Banda Aceh.

Sebanyak sepuluh ekor hiu dari masingmasing jenis yang diteliti diukur panjang totalnya menggunakan meteran sebelum dilakukan pengambilan sampel daging. Sampel ikan hiu yang dikoleksi tidak didasarkan pada keseragaman ukuran, melainkan berdasarkan ketersediaannya di PPS Lampulo. Daging hiu bagian punggung yang mendekati sirip anterior pertama dikoleksi menggunakan alat bedah sebanyak 30-50 g/sampel untuk selanjutnya dibawa ke laboratorium dan dianalisis lebih lanjut (Cornish et al. 2007; Prastyo et al. 2017). Morfologi ikan hiu tikus dan hiu kejen yang dikoleksi disajikan pada Figure 1 .

\section{Analisis logam berat pada daging}

Prosedur pengujian kandungan logam pada daging hiu mengacu pada SNI 01-28961998 tentang Uji Cemaran Logam dalam Makanan (Table 1). Kandungan logam berat pada daging hiu diukur menggunakan metode spektrofotometri serapan atom (Shimadzu AA-7000, Jepang). Tahap destruksi untuk parameter $\mathrm{Pb}, \mathrm{Cd}$, dan $\mathrm{Cu}$ dilakukan dengan menimbang sebanyak $5 \mathrm{~g}$ sampel daging yang telah dicuci untuk kemudian dimasukkan ke dalam erlenmeyer $250 \mathrm{~mL}$. Sampel dihancurkan dengan ditambahkan $15 \mathrm{~mL}$ $\mathrm{HNO}_{3}$ 65\% lalu dipanaskan menggunakan hot plate. Sampel yang sudah menjadi cairan selanjutnya didinginkan dan dipindahkan kedalam labu ukur $100 \mathrm{~mL}$ dan ditambahkan akuabides sampai tanda batas. Sementara itu, untuk parameter $\mathrm{Hg}$, sampel yang telah didestruksi ditambahkan $10 \mathrm{ml} \mathrm{HNO}_{3} 65 \%$, $15 \mathrm{~mL} \mathrm{H}_{2} \mathrm{SO}_{4}$, akuades dan $5 \mathrm{~mL} \mathrm{~K} \mathrm{~S}_{2} \mathrm{O}_{8} 5 \%$. Selanjutnya ditambahkan $\mathrm{KMNO}_{4}$ sampai tanda batas lalu dipanaskan dengan menggunakan hot plate pada suhu $85^{\circ} \mathrm{C}$ selama dua jam. Sampel yang sudah menjadi larutan didiamkan selama 24 jam.

Nilai kandungan $\mathrm{Pb}, \mathrm{Cd}$, dan $\mathrm{Cu}$ dibaca menggunakan metode flame (flame atomic absorption spectrophotometry) sedangkan nilai kandungan $\mathrm{Hg}$ dibaca menggunakan metode cold-vapor (cold-vapor atomic absorption spectrophotometry) dengan panjang gelombang yang sesuai dengan logam berat yang dianalisis. Panjang gelombang yang digunakan untuk $\mathrm{Pb}, \mathrm{Hg}, \mathrm{Cu}$, dan $\mathrm{Cd}$ adalah $217,0 \mathrm{~nm}, 253,7 \mathrm{~nm}, 324,7 \mathrm{~nm}$ dan $228,8 \mathrm{~nm}$ (Sulistiono et al. 2018).

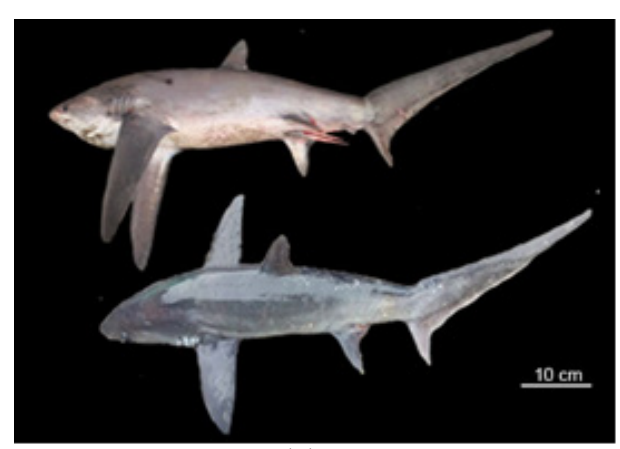

(a)

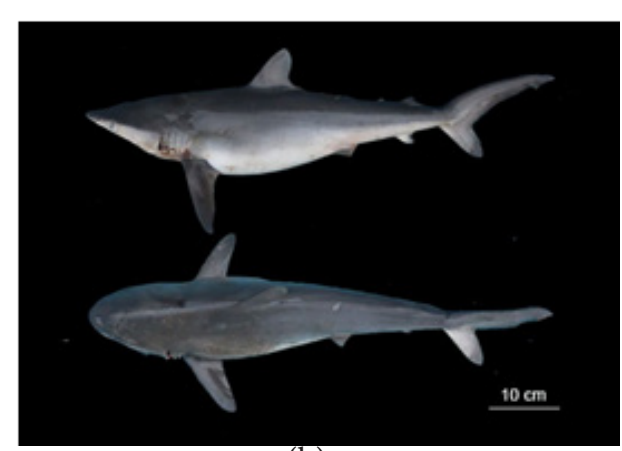

(b)

Figure 1 Morphology of (a) pelagic thresher (Alopias pelagicus) and (b) sliteye shark (Loxodon macrorhinus) Remarks, above: lateral view, bottom: dorsal view. 
Table 1 Observed parameters, detection limits, test methods and maximum tolerable concentration of heavy metal content in fish meat according to SNI 7387 (2009) and JEFCA (2004)

\begin{tabular}{ccccc}
\hline Heavy metals & Detection limits & Test methods & SNI (2009) & JEFCA (2004) \\
\hline $\mathrm{Pb}$ & $<0.0001$ & AAS (SNI 01-2896-1998) & $0.4 \mathrm{mg} / \mathrm{kg}$ & $0.03 \mathrm{mg} / \mathrm{kg}$ \\
$\mathrm{Hg}$ & $<0.0005$ & AAS (SNI 01-2896-1998) & $0.5 \mathrm{mg} / \mathrm{kg}$ & $0.05 \mathrm{mg} / \mathrm{kg}$ \\
$\mathrm{Cd}$ & $<0.0004$ & AAS (SNI 01-2896-1998) & $0.5 \mathrm{mg} / \mathrm{kg}$ & $0.01 \mathrm{mg} / \mathrm{kg}$ \\
$\mathrm{Cu}$ & $<0.0008$ & AAS (SNI 01-2896-1998) & $0.5 \mathrm{mg} / \mathrm{kg}$ & $0.02 \mathrm{mg} / \mathrm{kg}$ \\
\hline
\end{tabular}

\section{Batas aman konsumsi}

Penentuan batas aman konsumsi dari daging hiu dilakukan menggunakan perhitungan Maximum Tolerable Intake (MTI). Penghitungan ini dilakukan untuk mengetahui toleransi batas maksimum logam berat pada makanan yang dapat dikonsumsi dalam waktu satu minggu. Rumus yang digunakan untuk MTI mengacu pada Cahyani et al. (2018) sebagai berikut:

$\operatorname{MTI}(\mathrm{kg} / \mathrm{minggu})=\frac{\mathrm{MWI}(\mathrm{kg} / \mathrm{minggu})}{\mathrm{Ct}(\mathrm{mg} / \mathrm{kg})}$

Keterangan:

MTI adalah batas toleransi maksimum tingkat konsumsi ( $\mathrm{kg} / \mathrm{minggu})$

Maximum Weekly Intake (MWI) adalah batas maksimum tingkat konsumsi per minggu (kg/ minggu)

Ct adalah konsentrasi logam dalam daging ikan (mg/kg)

Nilai MWI ditentukan berdasarkan rumus berikut:

MWI $(\mathrm{kg} / \mathrm{minggu})=$ BW $(\mathrm{kg}) \times$ PTWI $(\mathrm{mg} / \mathrm{kg})$

Keterangan:

MWI adalah batas maksimum tingkat konsumsi per minggu ( $\mathrm{kg} / \mathrm{minggu})$

Provisional Tolerable Weekly Intake (PTWI) adalah nilai toleransi batas maksimum $(\mathrm{mg} / \mathrm{kg})$ yang dikeluarkan oleh Joint FAO/WHO Expert Committee on Food Additive (JEFCA) (2004) dan Standar Nasional Indonesia (SNI) 7387:2009 tentang batas maksimum cemaran logam berat dalam pangan (2009) (Table 2)
Ct adalah konsentrasi logam dalam daging ikan ( $\mathrm{mg} / \mathrm{kg})$

BW adalah berat rata-rata orang dewasa dan anakanak (kg) Indonesia mengacu pada Kemenkes RI (2010) yaitu $50 \mathrm{~kg}$ untuk orang dewasa dan $15 \mathrm{~kg}$ anak-anak.

\section{Analisis data}

Data hasil pengamatan disajikan dalam bentuk nilai kisaran, rata-rata dan standar deviasi. Hasil kandungan logam berat yang didapat dibandingkan dengan nilai baku mutu yang telah ditetapkan oleh SNI 7387 (2009) dan JEFCA (2004) (Table 1). Korelasi antara panjang dengan kandungan logam pada hiu ditentukan menggunakan regresi linier sederhana menggunakan bantuan perangkat lunak SPSS 22 versi Windows.

\section{HASIL DAN PEMBAHASAN Kandungan Logam Berat Daging Hiu Tikus dan Hiu Kejen}

Hiu tikus yang diteliti pada penelitian ini memiliki kisaran panjang total 220-320 $\mathrm{cm}$, sedangkan hiu kejen memiliki kisaran panjang total $77-162 \mathrm{~cm}$. Hasil pengukuran menunjukkan bahwa kandungan logam $\mathrm{Pb}$, $\mathrm{Cu}$, dan $\mathrm{Cd}$ pada daging hiu tikus dan hiu kejen masih berada dibawah batas deteksi alat ukur (Table 3). Sebaliknya, dari seluruh ikan hiu tikus dan hiu kejen yang dikoleksi, sebanyak $60 \%$ sampel yang diamati mengandung $\mathrm{Hg}$. Kisaran $\mathrm{Hg}$ pada hiu tikus berkisar antara

Table 2 Provisional tolerable weekly intake according to JEFCA (2004) and SNI 7387 (2009)

\begin{tabular}{ccc}
\hline \multirow{2}{*}{ Heavy metals } & \multicolumn{2}{c}{ PTWI $(\mathrm{mg} / \mathrm{kg}$ body weight per week } \\
\cline { 2 - 3 } & JEFCA & SNI 7387 \\
\hline $\mathrm{Pb}$ & 0.0250 & 0.025 \\
$\mathrm{Hg}$ & 0.0016 & 0.005 \\
$\mathrm{Cd}$ & 0.0070 & 0.007 \\
$\mathrm{Cu}$ & 3.5 & 0.035 \\
\hline
\end{tabular}


Table 3 Total length and concentration of $\mathrm{Cu}, \mathrm{Cd}, \mathrm{Pb}$, and $\mathrm{Hg}$ in pelagic thresher and sliteye shark meat

\begin{tabular}{cccccccccc}
\multirow{2}{*}{ Fish Name } & N (Ind) & \multicolumn{4}{c}{ Total Length $(\mathrm{cm})$} & \multicolumn{1}{c}{ Heavy Metal Concentration (mg/kg) } \\
\cline { 3 - 10 } & & Min & Max & Mean & STD & Cu & Cd & Pb & Hg \\
\hline Pelagic thresher & 10 & 220 & 320 & 217 & 30.19 & ND & ND & ND & ND-0.768 \\
Sliteye shark & 10 & 77 & 162 & 108 & 27.14 & ND & ND & ND & ND-0.708 \\
\hline
\end{tabular}

Information: $\mathrm{ND}=$ not detected

\begin{tabular}{ccccccc}
\multicolumn{6}{c}{ Table 4 Concentration of mercury $(\mathrm{Hg})$ in pelagic thresher and sliteye shark meat } \\
\hline \multirow{2}{*}{ Fish Name } & $\begin{array}{c}\text { Total Length } \\
\text { Range }(\mathrm{cm})\end{array}$ & N (Ind) & Min & Max & Mean & STD \\
\hline \multirow{5}{*}{ Pelagic thresher } & $<250$ & 2 & ND & ND & ND & ND \\
& $251-280$ & 3 & ND & 0.024 & 0.015 & 0.012 \\
\multirow{2}{*}{ Total } & $281-310$ & 3 & ND & 0.132 & 0.084 & 0.073 \\
& $>311$ & 2 & 0.425 & 0.768 & 0.596 & 0.242 \\
Sliteye shark & $\mathbf{2 2 0 - 3 2 0}$ & $\mathbf{1 0}$ & ND & $\mathbf{0 . 7 6 8}$ & $\mathbf{0 . 1 1 8}$ & $\mathbf{0 . 2 1 5}$ \\
& $<85$ & 2 & ND & 0.126 & 0.063 & 0.089 \\
& $101-125$ & 3 & ND & ND & ND & ND \\
Total & $>126$ & 2 & 0.030 & 0.063 & 0.047 & 0.022 \\
& $\mathbf{7 7 - 1 6 2}$ & $\mathbf{1 0}$ & ND & $\mathbf{0 . 7 0 8}$ & $\mathbf{0 . 1 4 7}$ & $\mathbf{0 . 2 5 5}$ \\
\hline
\end{tabular}

Information: $\mathrm{ND}=$ not detected

0,007-0,768 $\mathrm{mg} / \mathrm{kg}$ dengan nilai rata rata $0,118 \pm 0,215 \mathrm{mg} / \mathrm{kg}$. Sementara itu, kisaran merkuri pada hiu kejen berkisar antara 0,030$0,708 \mathrm{mg} / \mathrm{kg}$ dengan nilai rata rata $0,147 \pm$ 0,255 mg/kg (Table 4). Hiu tikus dan hiu kejen yang memiliki kisaran panjang total yang lebih besar cenderung memiliki kandungan $\mathrm{Hg}$ yang lebih tinggi dibandingkan dengan yang berukuran kecil.

Terdapat korelasi positif antara panjang total dengan kandungan $\mathrm{Hg}$ pada daging
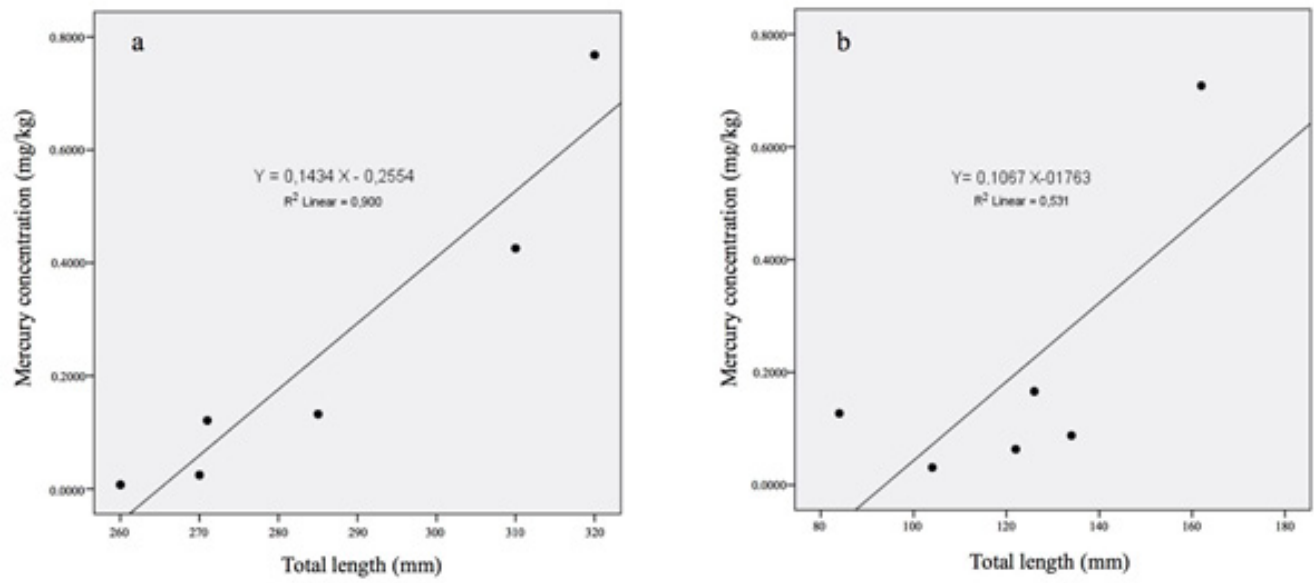

Figure 2 Correlation between total length and mercury $(\mathrm{Hg})$ concentration in (a) pelagic thresher and (b) sliteye shark hiu. Persamaan regresi linier antara panjang total dan kandungan $\mathrm{Hg}$ pada daging hiu tikus adalah $\mathrm{Y}=0,143 \mathrm{X}-0,255$ dengan nilai koefesien determinasi $\left(\mathrm{R}^{2}\right)$ sebesar 0,9 (Figure $2(a))$. Sementara itu, persamaan regresi linier antara panjang total dan kandungan $\mathrm{Hg}$ pada daging hiu kejen adalah $\mathrm{Y}=0,106 \mathrm{X}-0,176$ dengan nilai koofesien determinasi $\left(\mathrm{R}^{2}\right)$ yang lebih rendah yaitu sebesar 0,5 (Figure $2(b)$ ). 

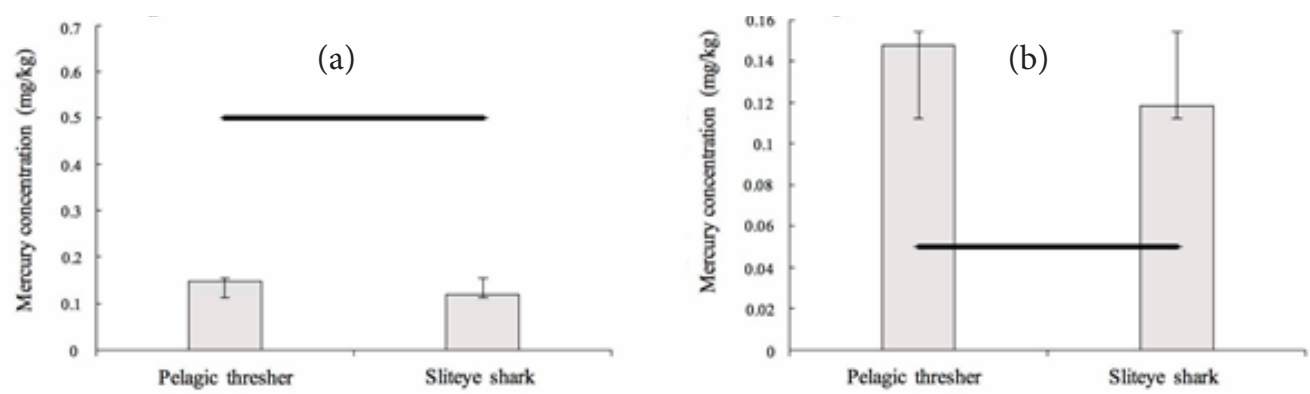

Figure 3 Concentration of mercury $(\mathrm{Hg})$ in the pelagic thresher and sliteye shark compared to (a) SNI 7387; (b) JEFCA 2004; (- ) maximum tolerable concentration of $\mathrm{Hg}$.

\section{Batas aman konsumsi}

Konsentrasi Hg pada daging hiu tikus dan hiu kejen masih berada di bawah baku mutu yang ditetapkan oleh SNI 7387 (2009) yaitu $0,5(\mathrm{mg} / \mathrm{kg})$, namun telah melebihi batas baku mutu yang telah ditetapkan oleh JEFCA (2004) sebesar 0,05 (mg/kg) (Figure 3). Nilai MWI daging hiu tikus dan hiu kejen terhadap orang dewasa dan anak-anak mengacu pada PTWI SNI 7387 (2009) yaitu masing-masing sebesar $0,25 \mathrm{mg} / \mathrm{kg}$ dan $0,075 \mathrm{mg} / \mathrm{kg}$. Dengan demikian, batas toleransi maksimum daging hiu tikus yang dapat dikosumsi oleh orang dewasa dan anak-anak dalam waktu satu minggu menurut SNI adalah masing masing sebesar 1,690 kg/minggu dan 0,507 kg/ minggu. Batas toleransi maksimum daging hiu kejen yang dapat dikosumsi oleh orang dewasa dan anak-anak dalam waktu satu minggu menurut SNI 7387 adalah masing masing sebesar $2,112 \mathrm{~kg} /$ minggu dan 0,633 $\mathrm{kg} /$ minggu (Table 5).

Dari 20 sampel daging hiu tikus dan hiu kejen yang diperiksa, keberadaan $\mathrm{Pb}, \mathrm{Cu}$, dan Cd tidak terdeteksi. Sebaliknya, $60 \%$ dari total sampel daging hiu yang diperiksa (baik hiu kejen dan hiu tikus) terdeteksi mengandung Hg. Ketiadaan logam $\mathrm{Pb}, \mathrm{Cu}$, dan $\mathrm{Cd}$ dalam daging hiu tikus dan hiu kejen diduga berkaitan erat dengan minimnya sumber pencemar ketiga logam tersebut di perairan sekitar daerah penangkapan hiu. Amin et al. (2011) dan Agustina (2014) mengungkapkan bahwa sumber utama cemaran $\mathrm{Pb}, \mathrm{Cu}$, dan $\mathrm{Cd}$ di perairan umumnya berasal dari aktivitas industri besar seperti industri baterai, industri cat, industri keramik dan industri perlengkapan medis. Beberapa peneliti melaporkan bahwa kandungan $\mathrm{Pb}$, $\mathrm{Cu}$, dan $\mathrm{Cd}$ di kawasan perairan Aceh masih berada di bawah baku mutu yang ditetapkan. Sebagai contoh, Pratama et al. (2019) melaporkan bahwa kandungan $\mathrm{Pb}$ di perairan sekitar PPS Lampulo masih berada dibawah baku mutu. Komarwidjaja et al. (2017) dan Warni et al. (2017) juga melaporkan hal yang sama terhadap kandungan $\mathrm{Cu}$ dan $\mathrm{Cd}$ di perairan pesisir Kabupaten Aceh Utara dan perairan pelabuhan Jetty Meulaboh, Aceh Barat. Meskipun kandungan $\mathrm{Pb}, \mathrm{Cu}$ dan Cd pada daging hiu tidak terdeteksi dalam penelitian ini, akan tetapi keberadaan logam ini telah dilaporkan terdapat pada beberapa jenis hiu lain dari berbagai kawasan berbeda. Salah satunya adalah hasil penelitian Adel et al. (2016), yang melaporkan adanya kandungan $\mathrm{Pb}, \mathrm{Cu}$, dan $\mathrm{Cd}$ masing-masing sebesar 0,12 $\pm 0,03 \mathrm{mg} / \mathrm{kg}, 7,49 \pm 0,25 \mathrm{mg} / \mathrm{kg}$ dan $0,11 \pm$ $0,03 \mathrm{mg} / \mathrm{kg}$ pada hiu Carcharhinus dussumieri

Table 5 Safety level of consumption of pelagic thresher and sliteye shark according to JEFCA (2004) and SNI 7387

\begin{tabular}{cccccc}
\hline \multirow{2}{*}{ PTWI (mg/kg) } & Fish Name & \begin{tabular}{c} 
MWI \\
\cline { 3 - 6 }
\end{tabular} & $\begin{array}{c}\text { MTI } \\
(\mathrm{mg} / \mathrm{kg})\end{array}$ & $\begin{array}{c}\text { MWI } / \text { week }) \\
(\mathrm{mg} / \mathrm{kg})\end{array}$ & $\begin{array}{c}\text { MTI } \\
(\mathrm{kg} / \text { week })\end{array}$ \\
\hline \multirow{2}{*}{ JEFCA (0.0016) } & Pelagic thresher & 0.08 & 0.540 & 0.024 & 0.162 \\
& Sliteye shark & 0.08 & 0.676 & 0.024 & 0.202 \\
& Pelagic thresher & 0.25 & 1.690 & 0.075 & 0.507 \\
& Sliteye shark & 0.25 & 2.112 & 0.075 & 0.633 \\
\hline
\end{tabular}


yang tertangkap di perairan sekitar kawasan industri Teluk Persia.

Kandungan $\mathrm{Hg}$ pada daging hiu tikus berkisar antara 0,007 sampai $0,768 \mathrm{mg} / \mathrm{kg}$ dengan nilai rata-rata sebesar $0,147 \pm 0,255$ $\mathrm{mg} / \mathrm{kg}$, sedangkan kandungan $\mathrm{Hg}$ pada daging hiu kejen berkisar antara 0,030 sampai 0,708 $\mathrm{mg} / \mathrm{kg}$ dengan nilai rata rata sebesar $0,118 \pm$ $0,215 \mathrm{mg} / \mathrm{kg}$. Besarnya nilai standar deviasi kandungan $\mathrm{Hg}$ pada kedua jenis hiu tersebut diduga dipengaruhi oleh keragaman ukuran sampel yang diteliti. Disamping itu, besarnya standar deviasi juga dilaporkan dipengaruhi oleh pola makan hiu (Endo et al. 2008; Adel et al. 2016). Hiu demersal dapat menghabiskan beberapa bulan tanpa makan, selama periode tersebut hiu hanya menggunakan cadangan lemak yang merupakan tempat terakumulasinya logam berat (Endo et al. 2008; Adel et al. 2016). Besarnya nilai standar deviasi kandungan Hg pada hiu juga pernah diungkapkan oleh Lozano-Bilbao et al. (2018) terhadap tiga jenis hiu (Deania profundorum, Centrophorus uyato dan Centrophorus squamosus) yang tertangkap di perairan Makronesia.

Kandungan rata-rata $\mathrm{Hg}$ pada hiu tikus dan hiu kejen yang didaratkan di PPS Lampulo masih lebih tinggi dibandingkan dengan kandungan rata-rata $\mathrm{Hg}$ pada hiu Prionace glauca yang tertangkap di kawasan perairan Pasifik Tenggara, mencapai 0,048 $\pm 0,03 \mathrm{mg} / \mathrm{kg}$ (Lopes et al. 2013). Sebaliknya, kandungan $\mathrm{Hg}$ pada hiu tikus dan hiu kejen masih lebih rendah dibandingkan dengan hiu Sphyrna lewini dan Caraharinus porosus yang tertangkap di kawasan perairan Trinidad dan Tobago dengan kisaran nilai antara 0,007-1,899 mg/ $\mathrm{kg}$ dan 0,006-3,268 mg/kg (Mohammed dan Mohammed 2017). Dibadingkan dengan beberapa jenis ikan lain yang tercemar $\mathrm{Hg}$ di perairan Indonesia, hiu tikus dan hiu kejen memiliki kandungan $\mathrm{Hg}$ yang lebih tinggi dibandingkan dengan ikan rejung (Sillago sihama) yang tertangkap di muara sungai Donan, Cilacap, Jawa Tengah (0,11-0,56 mg/ $\mathrm{kg}$ ), akan tetapi masih lebih rendah dibanding ikan kakap putih (Chrysaphrys aurata) yang tertangkap di perairan laut Kabupaten Gorontalo Utara dengan kandungan rata-rata
Hg sebesar 1,50 mg/kg (Cahyani et al. 2016; Mahmud et al. 2017).

Keberadaan Hg pada daging hiu tikus dan hiu kejen dalam penelitian ini diduga berkaitan erat dengan meningkatnya cemaran Hg di kawasan perairan Aceh. Navarro et al. (2012), mengungkapkan bahwa sumber utama Hg di perairan umumnya berasal dari aktivitas industri dan pertambangan. Di samping itu, Yulis (2018), juga menjelaskan bahwa pertambangan emas khususnya secara tradisional merupakan faktor utama penyebab meningkatnya cemaran $\mathrm{Hg}$ di perairan. Cemaran $\mathrm{Hg}$ di perairan Aceh akibat aktivitas pertambangan emas telah dilaporkan terjadi di beberapa kawasan perairan seperti muara Krueng Sabee, muara Krueng Panga dan muara Krueng Teunom, Kabupaten Aceh Jaya (Purnawan et al. 2017) serta perairan Sirkulat, Kecamatan Sawang, Kabupaten Aceh Selatan (Emelda et al. 2017). Cemaran Hg akibat industri pertambangan gas juga dilaporkan terjadi di perairan pesisir Kota Lhoksemawe dan Aceh Utara (Komarawidjaja et al. 2017). Walaupun demikian, penelitian lanjutan masih perlu dilakukan untuk mengkaji korelasi antara daerah tangkapan hiu dengan kandungan $\mathrm{Hg}$ pada daging hiu tikus dan hiu kejen. Hal ini disebabkan karena penelitian ini hanya terbatas mengkaji kandungan logam berat pada hiu yang didaratkan di PPS Lampulo tanpa melakukan penelusuran lebih lanjut terkait daerah tangkapan hiu.

Hasil penelitian mengungkapkan bahwa hiu tikus cenderung memiliki kandungan $\mathrm{Hg}$ yang lebih tinggi dibanding dengan hiu kejen. Menurut Adel et al. (2016) tingginya kandungan $\mathrm{Hg}$ pada hiu sangat dipengaruhi oleh ukuran panjang, tingkat trofik dan habitat. Rata-rata hiu tikus yang tertangkap pada penelitian ini memiliki ukuran yang lebih besar dibandingkan dengan hiu kejen. Hal ini diperkuat dengan adanya hasil analisis korelasi positif antara panjang total hiu dengan kandungan Hg. Hasil penelitian Lopes et al. (2013) juga ikut mengungkapkan adanya korelasi positif antara kandungan $\mathrm{Hg}$ dan $\mathrm{Pb}$ dengan panjang total hiu Carcharhinus falciformis.

Hg dapat masuk kedalam tubuh hiu melalui 
respirasi, difusi, dan konsumsi makanan yang terkontaminasi $\mathrm{Hg}$ (Cahyani et al. 2016). Matulik et al. (2017) melaporkan bahwa sebagian besar sumber logam berat yang terdapat pada hiu, berasal dari makanan yang dikonsumsi. Dalam tingkatan tropik, kedua jenis hiu tersebut tergolong dalam konsumen tingkat atas sehingga proses bioakumulasi dan biomagnifikasi $\mathrm{Hg}$ menjadi lebih tinggi. Hiu tikus yang dikoleksi dalam penelitian ini cenderung memiliki ukuran yang lebih besar dibandingkan dengan hiu kejen, sehingga jumlah makanan, akumulasi dan magnifikasi Hg ikut menjadi lebih besar. Disamping itu, hiu tikus juga dilaporkan memiliki komposisi makanan yang lebih beragam disertai daerah jelajah yang lebih luas dibandingkan hiu kejen (White et al. 2006; Lesmana et al. 2018).

Sampai saat ini, hiu tikus dan hiu kejen masih menjadi salah satu ikan konsumsi khususnya bagi masyarakat Aceh. Walaupun demikian, informasi terkait keamanan pangan dalam mengkonsumsi daging hiu masih jarang diungkap. Berdasarkan hasil penelitian, diketahui bahwa kandungan $\mathrm{Hg}$ pada daging ikan hiu tikus dan hiu kejen masih berada dibawah baku mutu yang ditetapkan oleh SNI 7387 (2009) akan tetapi telah melebihi ambang batas baku mutu yang ditetapkan JEFCA (2004). Keberadaan Hg yang telah melebihi baku mutu SNI juga telah dilaporkan terdapat pada beberapa jenis ikan lain seperti ikan rejung (Sillago sihama) (Cahyani et al. 2016), ikan kakap putih (Chrysaphrys aurata) (Mahmud et al. 2017) dan ikan nike (Awaous melanocephalus) (Mohamad et al. 2015).

Penentuan batas aman konsumsi (Maximum Tolerable Intake) merupakan salah satu upaya untuk menghindari dampak buruk yang dapat ditimbulkan logam berat jika masuk ke dalam tubuh (Barokah et al. 2019). Hasil penelitian mengungkapkan bahwa dalam skala mingguan, hiu kejen dapat dikonsumsi lebih banyak dibandingkan dengan hiu tikus. Batas toleransi maksimum daging hiu tikus yang dapat dikosumsi oleh orang dewasa dan anak anak dalam waktu satu minggu menurut SNI 7387 (2009) adalah masing masing sebesar $1,690 \mathrm{~kg} /$ minggu dan $0,507 \mathrm{~kg} /$ minggu. Sementara itu, untuk hiu kejen masing masing yaitu sebesar $2,112 \mathrm{~kg} /$ minggu dan $0,633 \mathrm{~kg} /$ minggu. Nilai ini masih lebih tinggi dibandingkan dengan batas aman konsumsi ikan rejung (Sillago sihama) yang tertangkap di di muara sungai Donan, Cilacap $(0,620 \mathrm{~kg} / \mathrm{minggu}$ untuk orang dewasa dan $0,186 \mathrm{~kg} / \mathrm{minggu}$ untuk anak-anak) (Cahyani et al. 2016)

Konsumsi ikan yang mengandung $\mathrm{Hg}$ di luar batas aman konsumsi berpotensi menimbulkan efek kronik bagi tubuh. Cahyani et al. (2016) menyatakan bahwa akumulasi logam berat $\mathrm{Hg}$ di dalam tubuh manusia secara kronis dapat membahayakan dan mengganggu kesehatan manusia. Keracunan $\mathrm{Hg}$ dapat menyebabkan terjadinya kerusakan saluran pencernaan, gangguan kardiovaskular dan kegagalan ginjal akut (Agustina 2014). Logam berat Hg juga dapat menyebabkan kerusakan otak permanen dan kerusakan ginjal (Yulis 2018). Lebih lanjut menurut Putranto (2011), keracunan $\mathrm{Hg}$ berpotensi menggangu sistem saraf yang berdampak pada kelainan bicara, kerusakan motorik hingga abnormalitas sensorik.

\section{KESIMPULAN}

Kandungan logam berat $\mathrm{Pb}, \mathrm{Cu}$, dan $\mathrm{Cd}$ pada daging hiu tikus dan hiu kejen yang didaratkan di PPS Lampulo masih berada di bawah batas deteksi alat ukur. Kandungan $\mathrm{Hg}$ pada hiu tikus dan hiu kejen masih berada dibawah baku mutu SNI (2009), akan tetapi telah melebihi baku mutu yang ditetapkan oleh JEFCA (2004).

Penelitian lanjutan terkait korelasi antara daerah tangkapan hiu dengan kandungan $\mathrm{Hg}$ pada daging hiu tikus dan hiu kejen perlu dilakukan.

\section{UCAPAN TERIMA KASIH}

Ucapan terima kasih penulis haturkan kepada Laboratorium Balai Riset dan Standardisasi Industri (Baristand) Banda Aceh yang telah memfasilitasi pengujian logam berat. Terima kasih pula kepada pengelola PPS Lampulo yang telah menyediakan sarana pendukung dalam proses pengambilan sampel. Penelitian ini didukung oleh Pusat Kajian dan Konservasi Akuatik, Universitas Islam Negeri Ar-Raniry melalui program penelitian dasar 2019. 


\section{DAFTAR PUSTAKA}

Adel M, Conti GO, Dadar M, Mahjoub M, Copat C, Ferrante M. 2016. Heavy metal concentrations in edible muscle of whitecheekshark, Carcharhinusdussumieri (elasmobranchii, chondrichthyes) from the persian gulf: a food safety issue. Journal Food and Chemical Toxicology. 97(1): 135-140.

Agustina T. 2014. Kontaminasi logam berat pada makanan dan dampaknya pada kesehatan. Jurnal Teknobunga. 1(1): 5365.

Alaydrus IS, Fitriana N, Jamu Y. 2014. Jenis dan status konservasi ikan hiu yang tertangkap di tempat pelelangan ikan (TPI) Labuan Bajo, Manggarai Barat, Flores. Al-Kauniyah Jurnal Biologi. 7(2): 83-87.

Amin B, Afriyani E, Saputra MA. 2012. Distribusi spasial logam $\mathrm{Pb}$ dan $\mathrm{Cu}$ pada sedimen dan air laut permukaan di perairan tanjung buton Kabupaten Siak Provinsi Riau. Jurnal Teknobiologi. 2(1), 1-8.

Astuti I, Karina S, Dewiyanti I. 2016. Analisis kandungan logam berat $\mathrm{Pb}$ pada tiram Crassostrea cucullata di pesisir Krueng Raya, Aceh Besar. Jurnal Ilmiah Mahasiswa Kelautan dan Perikanan Unsyiah. 1(1): 104-113.

Barokah GR, Dwiyitno D, Nugroho I. 2019. Kontaminasi logam berat $(\mathrm{Hg}, \mathrm{Pb}$, dan Cd) dan batas aman konsumsi kerang hijau (Perna virdis) dari perairan Teluk Jakarta di musim penghujan. Jurnal Pascapanen dan Bioteknologi Kelautan dan Perikanan. 14(2): 95-106.

[BSN] Badan Standardisasi Nasional. 2009. Batas Maksimum Cemaran Logam Berat dalam Pangan. Jakarta (ID): Badan Standardisasi Nasional.

Cahyani N, Batu DTFL, Sulistiono. 2016. Kandungan logam berat $\mathrm{Pb}, \mathrm{Hg}, \mathrm{Cd}$, dan $\mathrm{Cu}$ pada daging ikan rejung (Sillago sihama) di Estuari Sungai Donan, Cilacap, Jawa Tengah. Jurnal Pengolahan Hasil Perikanan Indonesia. 19(3): 267-276.

Cornish AS, Ng WC, Ho VCM, Wong HL, Lam JCW, Leung KMY. 2007. Trace metals and organochlorines in the bamboo shark Chiloscyllium plagiosum from the southern waters of Hong Kong, China. Science of Total Environment. 2(1): 335-345.

Das K, Beans C, Holsbeek L, Berrow SD, Rogan E, Bouquegneau JM. 2003. Marine mammals from northeast Atlantic: evaluation of their trophic status by $\mathrm{d} 13 \mathrm{C}$ and $\mathrm{d} 15 \mathrm{~N}$ and influence on their trace metal concentrations. Marine Environmental Research. 1(56): 349-365.

[DSN] Dewan Standardisasi Nasional. 1998. Uji Cemaran Logam dalam Makanan. Jakarta (ID): Dewan Standardisasi Nasional.

Dharmadi, Fahmi, Triharyuni S. 2012. Aspekbiologi dan fluktuasi hasil tangkapan cucut tikusan, (Alopias Pelagicus) di samudera hindia. Bawal. 4(3):131-139.

Emelda C, Supriatno, Ali MS. 2017. Tingkat akumulasi merkuri $(\mathrm{Hg})$ pada organ tubuh kelas gastropoda di Kawasan Perairan Sungai Sikulat Kecamatan Sawang Kabupaten Aceh Selatan. Jurnal EduBio Tropika. 5(1): 21-26.

Endo T, Hisamici Y, Haraguchi K, Kato Y, Ohta C, Koga N. 2008. Hg, Zn and Cu Levels in the muscle and liver of tiger sharks (Galeocherdo curvier) from The Coast of Ishigaki Island, Japan: relationship beetwen metal concentrations and body length. Marine Pollution Bulletin. 56(1): 1774-1780.

Hidayah AM, Purwanto, Soeprobowati TR. 2014. Biokonsentrasi faktor logam berat $\mathrm{Pb}, \mathrm{Cd}, \mathrm{Cr}$ dan $\mathrm{Cu}$ pada ikan nila (Oreochromis niloticus linn.) di karamba danau rawa pening. Jurnal Bioma. 16(1): 1-9.

Indirawati SM. 2017. Pencemaran logam berat $\mathrm{Pb}$ dan $\mathrm{Cd}$ dan keluhan kesehatan pada masyarakat di Kawasan Pesisir Belawan. Jurnal Jumantik. 2(2): 54-60.

[JECFA] Joint FAO/WHO Expert Committee on Food Additive. 2004. Evaluation of Certain Food Additives and Contaminants. WHO technical report series. Rome, Italy, $176 \mathrm{pp}$.

[KEMENKES RI] Kementerian Kesehatan Republik Indonesia. 2010. Pedoman 
Pelayanan Antenatal Terpadu. Jakarta (ID): Direktur Jenderal Bina Kesehatan Masyarakat Kementerian Kesehatan Republik Indonesia.

Komarawidjaja W, Riyadi A, Garno YS. 2017. Status kandungan logam berat perairan pesisir Kabupaten Aceh Utara dan Kota Lhokseumawe. Jurnal Teknologi Lingkungan. 18(2): 251-258.

Lesmana F, Ulfah M, Rizwan MT. 2018. Identifikasi spesies hiu yang tertangkap di Perairan Utara Aceh. Jurnal Ilmiah Kelautan dan Perikanan Unsyiah. 3(1): 39-45.

Lopes SA, Abarca NL, Melendez RC. 2013. Heavy metal cocentration of two highly migratory shark (Prionace glauca and Isurus oxyrinchus) in The Southeastern Pacific Water: comments on public health and conservation. Tropical Conservation Science. 6(1): 126-137.

Lozano-Bilbao EL, Lozano G, Gutiérrez AJ, Rubio C, Hardisson A. 2018. Mercury, cadmium and lead content in demersal sharks from the macaronesian islands. Environmental Science and Pollution Research. 25(21): 21251-21256.

Maftuch, Marsoedi, Putri VD, Lulloh MH, Wibisono FKH. 2015. Studi ikan bandeng (Chanos chanos) yang dibudidayakan di tambak tercemar limbah kadmium (Cd) dan timbal $(\mathrm{Pb})$ di Kalanganyar, Sidoarjo, Jawa Timur terhadap histopatologi hati, ginjal dan insang. Journal of Environmental Engineering \& Sustainable Technology. 2(2): 114-122.

Mahmud M, Lihawa F, Banteng B, Desei F, Saleh Y. 2017. Konsentrasi merkuri pada ikan di perairan laut Sulawesi akibat penambangan emas tradisional Buladu Kabupaten Gorontalo Utara. Jurnal Pengelolaan Lingkungan Berkelanjutan. 1(3): 7-17.

Matulik AG, Kerstetter DW, Hammerschlang $\mathrm{N}$, Divoll T, Hammerschidt CR, Evers DC. 2017. Bioaccumulation and biomagnification of mercury and methylmercury in four sympatric coastal sharks in a protected subtropical lagoon. Marine Pollution Bulletin. 116(1): 357364.
Mohamad NW, Sahami FM, Panigoro. 2015. Analisis kandungan merkuri pada ikan nike di Kota Gorontalo. Jurnal Ilmiah Perikanan dan Kelautan. 3(3): 100-102.

Mohammed A, Mohammed T. 2017. Mercury, arsenic, cadmium and lead in two commercial shark species (Sphyrna lewini and Caraharinus porosus) in Trinidad and Tobago. Marine Pollution Bulletin. 119(3): 214-218.

Navarro P, Amouroux D, Ngh DT, RochelleNewall E, Ouillon S, Arfi R, Thuoc CV, Mari X, Torréton JP. 2012. Fate and tidal transport of butyltin and mercury compounds in the waters of the tropical bach dang estuary (Haiphong, Vietnam). Marine Pollution Bulletin. 64(9):1789-1798.

Pratama R, Muhammad M, Rusydi I. 2019. Studi sebaran logam berat timbal $(\mathrm{Pb})$ pada perairan pelabuhan perikanan samudera (PPS) Lampulo Banda Aceh. Jurnal Ilmiah Mahasiswa Kelautan Perikanan Unsyiah. 4(4): 185-191.

Prastyo Y, Batu, DTFL, Sulistiono. 2017. Kandungan logam berat $\mathrm{Cu}$ dan $\mathrm{Cd}$ pada ikan belanak di estuari Sungai Donan, Cilacap, Jawa Tengah. Jurnal Pengolahan Hasil Perairan Indonesia. 20(1): 18-27.

Purnawan S, Rahman R, Karina S. 2017. Kandungan merkuri pada substrat dasar di kawasan muara Krueng Sabee, Krueng Panga, dan Krueng Teunom, Kabupaten Aceh Jaya. Jurnal Ilmu-ilmu Perairan, Pesisir dan Perikanan. 6(3): 265-272.

Putranto TT. 2011. Pencemaran logam berat merkuri (Hg) pada air tanah. Jurnal Teknik. 32(1): 62-71.

Rahayu NI, Rosmaidar, Hanafiah M, Karmil FT, Helmi ZT, Daud R. 2017. Pengaruh paparan timbal $(\mathrm{Pb})$ terhadap laju pertumbuhan ikan nila (Oreochromis nilloticus). Jurnal Ilmiah Mahasiswa Veteriner. 1(4): 658-665.

Rizkiana L, Karina S, Nurfadillah. 2017. Analisis timbal $(\mathrm{Pb})$ pada sedimen dan air laut di kawasan pelabuhan nelayan Gampong Deah Glumpang Kota Banda Aceh. Jurnal Ilmiah Mahasiswa Kelautan dan Perikanan Unsyiah. 2(1): 89-96.

Siregar YI, Edward J. 2010. Faktor konsentrasi 
$\mathrm{Pb}, \mathrm{Cd}, \mathrm{Cu}, \mathrm{Ni}, \mathrm{Zn}$ dalam sedimen perairan pesisir Kota Dumai. Maspari Journal. 1(1): 1-10.

Sudarmaji, Mukono J, Corie IP. 2006. Toksikologi logam berat B3 dan dampaknya terhadap kesehatan. Jurnal Kesehatan Lingkungan. 2(2):129-142.

Sulistiono, Irawati Y, Batu DTFL. 2018. Kandungan logam berat pada ikan beloso (Glosogobius giuris) di Perairan Segara Anakan Bagian Timur, Cilacap, Jawa Tengah, Indonesia. Jurnal Pengolahan Hasil Perikanan Indonesia. 21(3): 423432.

Warni D, Karina S, Nurfadillah. 2017. Analisis logam $\mathrm{Pb}, \mathrm{Mn}, \mathrm{Cu}$, Dan $\mathrm{Cd}$ pada sedimen di Pelabuhan Jetty Meulaboh, Aceh Barat. Jurnal Ilmiah Mahasiswa Kelautan dan Perikanan Unsyiah. 2(2): 246-253.

White WT, Last PR, Stevens JD, Yearsley GK, Fahmi, Dharmadi. 2006. Economically
Important Sharks and Rays of Indonesia. Canberra (AU): Australian Centre for International Agricultural Research. Canberra.

Yulis PAR. 2018. Analisis kadar logam merkuri $(\mathrm{Hg})$ dan $(\mathrm{Ph})$ air Sungai Kuantan terdampak penambangan emas tanpa izin (PETI). Orbital: Jurnal Pendidikan Kimia. 2(1): 28-36.

Zulfahmi I, Affandi R, Batu DTFL. 2014. Kondisi biometrik ikan nila (Oreochromis niloticus Linnaeus 1758) yang terpapar merkuri. Jurnal Iktiologi Indonesia. 14(1): 37-48.

Zulfahmi I, Affandi R, Batu DTFL. 2015. Perubahan struktur histologis insang dan hati ikan nila (Oreochromis niloticus Linnaeus 1758) yang terpapar merkuri. Jurnal Edukasi dan Sains Biologi. 4(1): 2531. 